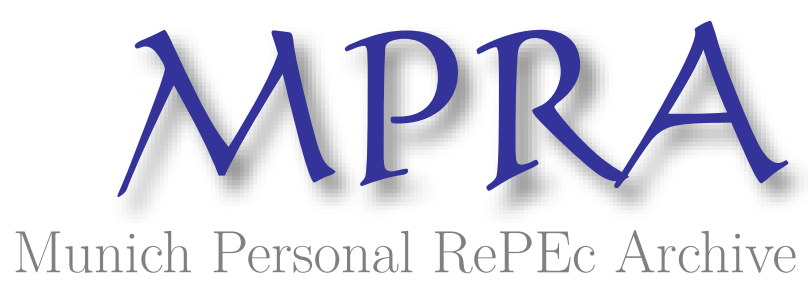

\title{
Corridors, Coordination and the Entrepreneurial Theory of the Market Process
}

Boettke, Peter

George Mason University

2010

Online at https://mpra.ub.uni-muenchen.de/33597/

MPRA Paper No. 33597, posted 21 Sep 2011 16:46 UTC 


\title{
Corridors, Coordination, and the Entrepreneurial Theory of the Market Process
}

\author{
Peter J. Boettke \\ George Mason University \\ Daniel J. D'Amico \\ Loyola University New Orleans
}

\begin{abstract}
:
Daniel Klein (Klein 1997, Klein and Orsborn 2009 and Klein and Briggeman forthcoming) and Israel Kirzner (forthcoming) have been engaged in a debate concerning how economists should understand and use the terms "coordination" and "economic goodness". Klein and Briggeman (forthcoming) contend that Kirzner suffers from excessive ambition scientifically. The authors claim Kirzner's reliance and identification with "the Misesian image of science" threatens to discredit his more sensible contributions (e.g., market processes are driven towards progress by competitive entrepreneurial discovery). We offer a response to Klein and Briggeman's claim that loose, vague and indeterminate forms of economic reasoning make for a more robust political economy. In doing so, we also explain the theoretical context surrounding Kirzner's theory of the entrepreneurial market process. While we agree with Klein and Briggeman's critique of scientism and formalism, we emphasize the nature of the debates over market theory and the price system that Kirzner was engaging in order to understand the reasons behind his methods and the theoretical insights they provide. Rather than the source of his failure, we view Kirzner's "excessive ambitions" to provide a scientific foundation of the market process as the source of his great success as an economic theorist.
\end{abstract}

JEL Codes: B31, B53

KEYWORDS: Austrian Economics, Disequilibrium Dynamics, Entrepreneurship, Kirzner, Market Process 


\section{Corridors, Coordination, and the Entrepreneurial Theory of the Market Process}

We have been asked to contribute to an on-going conversation between Daniel Klein (Klein 1997, Klein and Orsborn 2009 and Klein and Briggeman forthcoming) and Israel Kirzner (forthcoming) who have been engaged in a debate concerning how economists should understand and use the terms "coordination" and "economic goodness". Klein and Briggeman (forthcoming) contend that Kirzner suffers from excessive ambition scientifically. '[He] makes 'always' - or 'necessarily' - type claims categorical claims - where the claims instead should be 'usually' or 'by and large' (p. 2)." To Klein and Briggeman, Kirzner's reliance and identification with "the Misesian image of science" threatens to discredit his more sensible contributions - market processes are (Klein and Briggeman hope to add the caveat "usually") driven towards progress by competitive entrepreneurial discovery.

There are more arguments in Klein and Briggeman's paper than we could hope to address in this short paper. Kirzner's (forthcoming) response goes a long way toward sorting these issues out and demonstrating where Kirzner is being misread by Klein and Briggeman. He writes, "[their] criticisms are embedded in an idiosyncratic doctrinal history framework (relating particularly to the Austrian tradition (ibid, p. 1).” Kirzner continues to clarify that even though an "objective understanding of economic processes... demonstrates distinct economic advantages for a classical liberal society does not, in principle, nullify the need to ensure that the public does not dismiss such demonstrations as motivated by ideologically based preconceptions (p. 2)." Kirzner explains that "Modern Austrian Economics, finds its roots in Mises and Hayek not for 
any 'praxeological' foundations, but for the insights and understandings to be found in their work, concerning the nature of the market process (p. 5)."

We try to respond to Klein and Briggeman's claim that loose, vague and indeterminate forms of economic reasoning make for a more robust political economy. In response, we explain the theoretical context surrounding Kirzner's theory of the entrepreneurial market process. Readers must understand the nature of the debates over market theory and the price system that Kirzner was engaged within in order to understand the reasons behind his methods and the theoretical insights they provide. Kirzner's research project was aimed to fill theoretical gaps within the neoclassical research project and we would argue he succeeds on this margin.

Klein and Briggeman support loose, vague and indeterminate reasoning as opposed to axiomatic reasoning. Klein's (Klein 1997, Klein 2009, Klein and Lucas 2009, Klein and Orsborn 2009, Klein and Briggeman forthcoming) research offers unique interpretations of concepts first introduced by Adam Smith. Klein (Klein 2005) also holds unique positions regarding the roles of positive and normative science in economics. We agree with the critique of formalism and scientism, but we also argue that economists should not condemn performing economics as a positive social science altogether. There is, we contend, a way to do positive economics without committing the intellectual errors that Klein believes are necessary if one is to stress the scientific nature of economic reasoning. 
Rather than the source of his failure, we view Kirzner's "excessive ambitions" (to provide a scientific foundation of the market process) as the source of his great success as an economic theorist. Kirzner is perhaps too humble of a scholar to take such credit, constantly giving credit to his teacher Mises, rather than emphasizing his own contributions. But the questions he tackled in his development of the entrepreneurial theory of the market process are at the core of the scientific legitimacy behind the entire neoclassical enterprise of market theory and the price system.

Kirzner's creative synthesis of Mises and Hayek, was employed to address a theoretical lacuna in neoclassical theory. Kenneth Arrow (1959) exposed this gap when he explained that in a world where everyone is postulated to be a price taker, there is no explanation left for how prices would ever change to clear markets? A theory of disequilibrium adjustment was required to complete the neoclassical theory of the competitive market, but no such theory was possible that treated prices as parametric. Franklin Fisher (1983, p. 3) explained that the neoclassical theory of the market faced a dilemma unless it had appropriate disequilibrium foundations. Without a theory to explain the process of adjustment from disequilibrium to equilibrium, the first and second welfare theorems, the corresponding notions of exchange efficiency, productive efficiency and product-mix efficiency would be little more than a set of unjustified beliefs.

Kirzner provides us with the ability to cope with disequilibrium, and how market participants learn through time and adjust (if the data of the market were frozen) to a point of equilibrium. Given the significance of the problem identified by Arrow and Fisher, Kirzner's theoretical contributions to scientific economics should not be 
undersold. $^{2}$ One must place Kirzner in his appropriate theoretical context in order to understand the way he synthesizes Mises and Hayek to make an original contribution to the neoclassical theory of markets and prices.

Kirzner basically defends the project of theoretical economics from Adam Smith to Ludwig von Mises, F. A. Hayek and beyond. Too much of the Klein and Briggeman critique is tied to what they see as Kirzner's effort to create a unique Austrian identity axiomatic economics. We alternatively see Kirzner and modern Austrian economics as a crucial portion of the larger neoclassical project to understand the price system and the market economy (Boettke 1994 and 1996). There is an important distinction between mainline economic thinking and mainstream economic thinking. The mainline of economic science/policy is the consistent teaching throughout the history of the discipline that emphasizes the "interests" of individual decision-makers, the "invisible hand" of the market, and the way in which private property, free pricing, and profit and loss accounting steer economic activity so that social cooperation under the division of labor is made possible in a society of diverse and socially distant participants. The mainstream

\footnotetext{
${ }^{2}$ The interested reader is directed to the 2 volume reference work by Boettke and Prychitko, eds., Market Process Theories (1998) for a collection of the main papers on the market process from a mathematical, institutional, heterodox and Austrian perspective.

${ }^{4}$ The notion of the corridor came from Axel Leijonhufvud (1981) in his essay "The Wicksell Connection: Variations on a theme," in Information and Coordination. The basic idea is that inside of the corridor the self-correcting dynamics of the market are in operation, but economic crises occur when activity spills outside of the corridor and the forces of self-correction cannot be relied upon. For our purposes, Kirzner's focus is on economic activity that is in a disequilibrium situation, but inside the corridor. In this sense, entrepreneurial activity is not discoordinating, but always bringing in line the plans of economic actors with the underlying realities of tastes, technology, and resource scarcity. Kirzner's distinction between the underlying (tastes, technology, and resource constraints) and induced (prices and profit and loss) variables of the market should never be forgotten in assessing his theory of the entrepreneurial market process. See Kirzner, The Meaning of Market Process (1990).
} 
of economic science/policy, on the other hand, does not designate any substantive proposition. It is a sociological designation related to what is and what isn't scientifically fashionable at any given point. Sometimes the mainline and the mainstream are identical, other times they deviate from one another. It is our contention that whenever the mainstream significantly deviates from the mainline it becomes important to emphasize the unique contributions of particular schools of thought in the attempt to close that gap.

The classical political economy of Smith and Say contained elements of incentive analysis, a refined understanding about the role of local knowledge, and an appreciation of private property rights. Classical economists saw the market as a process of competitive rivalry and dynamic entrepreneurial discovery. They placed importance on the economics of organizations, and examined the political process with the same behavioral assumptions that they used to examine the market process. Kirzner plays an important role in this history rightly listed alongside Mises and Hayek.

While the development of marginal utility analysis and the subjective theory of value revolutionized the way economists thought at the turn of the $20^{\text {th }}$ century, the basic argumentative structure concerning broad brush political economy (including the concern with special interests and monopoly privileges) can be traced to the Scottish Enlightenment, the French Liberal tradition, the British Utilitarian Philosophers, and the Austrian School of Economics. Many of these same insights had to be rediscovered and reintroduced into the economic discourse in the post WWII era by the Chicago School, the UCLA property rights school, the Virginia School of Political Economy, the New Institutionalist School, and the modern Austrian school of economics. Without these "new developments" in the 1950s, 1960s, and 1970s, the mainstream deviation from the 
mainline teachings would have gone uncontested. And since the term neoclassical economics came increasingly in the 1940 s and 1950 s to represent a methodological position rather than a set of substantive propositions about the economy, the school labels played an extremely important role as an intellectual corrective to the hegemony of Keynesian macroeconomics and market-failure theory in microeconomics.

Kirzner's role in championing the Austrian school was no different from the role played by Friedman, Stigler, Becker and Lucas in championing the Chicago School, or Alchian and Demsetz in championing the UCLA property rights school, or Buchanan and Tullock in championing the Virginia school, or Coase, North and Williamson championing the New Institutionalist school. The counter-revolution of these traditions pushed back against the scientifically and politically fashionable mainstream, and brought economic thinking back (at least to a considerable extent) to the mainline of thinking from Adam Smith to F. A. Hayek. Kirzner and others guided this counterrevolution without which the excessively aggregative macroeconomic and institutionally antiseptic microeconomic theory that Samuelson ushered in would still dominate economic thinking.

We believe Klein and Briggeman have failed to stress this intellectual context of Kirzner's contribution to economics. But they err in another way as well. Because they fail to understand the context of Kirzner's contribution, they also misread his substantive theoretical contribution. Klein and Briggeman's criticism of Kirzner's fails to appreciate the distinction between the framework within which economic activity transpires and the activities themselves. To help in understanding Kirzner's contributions we suggest that the concept of "the corridor of economic activity" and the coordinating role of 
entrepreneurship within a given "corridor" is very useful and may go a long way to addressing Klein and Briggeman's criticisms. ${ }^{4}$

Kirzner treats the institutional framework of economic life as exogenously given, and examines instead economic activity within that existing framework. The exogenously given framework consists of the legal system, its enforcement, the monetary system, and the underlying moral set of beliefs that sustain the system of property, contract, and consent. Inside of this system, Kirzner examins how economic actors engage in open-ended choice. They discover the opportunities for mutually beneficial exchange and they act on price discrepancies to realize pure profit. They recognize the gains from novelty and innovation and they act upon those opportunities in pursuit of profit. To put the Kirznerian point in the context of the basic principles of economics, the entrepreneur not only ensures that the economic system tends to operate on the production possibilities frontier thanks to arbitrage, but the system also exhibits a ceaseless tendency to push the production possibilities frontier outward as entrepreneurs innovate in the delivery and production of existing products and new products to satisfy consumer demands. Ray Croc didn't invent the hamburger, French fries, or the milkshake. But Ray Croc did discover a new way to deliver them, and McDonald's has become an international symbol of capitalism and globalization. Bill Baumol (2002) has in fact described the entrepreneurial market economy as a free market innovation machine. Within the "corridor" of given institutions and the values that support those institutions (and provide them with legitimacy), the entrepreneurial activity of individuals (in both its arbitrage and innovative capacity) will lead to price signals and profit opportunities that steer individuals along the path to coordinate their plans with one 
another. When the most willing suppliers and the most willing demanders settle on the terms of exchange only then are the gains from trade and the gains from innovation realized.

There is nothing loose or vague or indeterminate about this, it instead follows directly from the logic of entrepreneurial discovery once all the subsidiary arguments are understood and accepted. To Kirzner, economic science is not a science of exact equilibrium states, but a science of tendencies and directions of change - what Hayek (1974) called pattern prediction. In the process of change some plans will obviously be upset, and others will be surprisingly satisfied, but provided economic activity stays inside the boundaries set by the corridor, the ceaseless change in the market place will be directed toward the alignment of the induced variables with the underlying variables of the market (and the realization of the gains from trade and the gains from innovation). Kirzner's coordination point, his point about the dovetailing of plans and his point on equilibration are all simply affirming the basic economic point that individuals will realize mutual gains from trade. To put it in more Kirznerian language, individuals will be alert to that which is in their interest to be alert to; they will discover that which is in their interest to discover.

Here again, Klein and Briggeman fail to recognize the broader context of debate surrounding Kirzner's position. Kirzner's (1998) proposes that social coordination defined as the harmonious coexisting plans of interacting human individuals - be considered as a proxy to represent social welfare. Again Klein and Briggeman dislike Kirzner's use of the term coordination in favor of alternatives laid out in Klein and Orsborn (2009). To them, Kirzner is too positivist and they prefer a definition for 
coordination that implies reference to a "super-knowledgable" and normatively intuitive onlooker (See also Klein forthcoming). We propose that this definition of concatenate coordination is not Smith's intention behind the impartial spectator as developed in The Theory of Moral Sentiments (1759) but it is instead something quite different. ${ }^{5}$ Kirzners's position - social coordination can proxy for social welfare - was a reaction to the arguments within mainstream welfare economics. Kirzner is attempting to provide an acceptable answer to his fellow economists on their terms that cultivates an appreciation for the entrepreneurial market process and the knowledge generating and system learning properties of the market process.

Louis Pasteur is quoted as saying that "fortune favors the prepared mind." Kirzner's entrepreneurial theory of the market process translates this critical insight into economics. It is not an insight that was new to him. Adam Smith (1776) captured the basic idea in his famous butcher, baker and brewer example, and even more in his example of the vast social cooperation under the division of labor evident in the exchange and production of the common woolen coat. Private property and freedom of contract, by steering individual interests in certain directions to realize the mutual gains from trade and capture the gains from innovation, leads to the "invisible hand" results of the market economy that Smith had identified. The entrepreneurial impulse to be alert to the opportunities to 'truck, barter and exchange' produces a dovetailing of economic plans such that social cooperation among strangers is realized and the productivity gains Smith

\footnotetext{
${ }^{5}$ Klein (2009) does provide an electronic data-base analysis of the history of the use of the term coordination. But we believe that his emphasis on specific use fails to capture the meaning of the concept, and that the idea of the coordination of economic activities has a much deeper meaning even if at times the terms used - cooperation and mutual cooperation are meant to capture the ideas of coordination (concatenate, mutual, and the dovetailing of plans).
} 
identified that follow from the division of labor (specialization and exchange) result in wealth creation and human betterment. To turn a blind eye to Kirzner's contributions, we contend, is to miss out on the essential Smithian ideas of specialization and exchange, complex coordination beyond computation; and cooperation without command. In short, Kirzner is the further elaboration of Smithian mainline economics in the context of midto late- $20^{\text {th }}$ century economics through a creative synthesis of the contributions of Mises (1949) and Hayek (1948) as embedded in Human Action and Individualism and Economic Order. Without this rendering of the Smithian position, the Samuelsonian sterility of economic teaching would have more of a grip on the intellectual imagination of economists than it already does. We believe that if Klein and Briggeman kept this context in mind that much of the criticisms they level against Kirzner would disappear, and that Klein's own Smithian project would be advanced through alliance with Kirzner and the Austrian school rather than splitting semantic hairs. 


\section{Bibliography}

Arrow, Kenneth (1959). "Toward a Theory of Price Adjustment," in Abramovitz (editor) Allocation of Economic Resources: Essays in honor of Bernard Francis Haley. Stanford: Stanford University Press.

Baumol, William (2002). The Free-Market Innovation Machine: Analyzing the Growth Miracle of Capitalism. Princeton: Princeton University Press.

Boettke, Peter J. (1994). "Alternative Paths Forward for Austrian Economics," in Boettke (editor) The Elgar Companion to Austrian Economics. Aldershot: Edward Elgar Publishing: pp. $601-616$.

Boettke, Peter J. (1996). "What is Wrong with Neolclassical Economics (And What is Still Wrong with Austrian Economics)," in Fred Foldvary (editor) Beyond Neoclassical Economics. Aldershot: Edward Elgar Publishing: 22-40.

Boettke, Peter J. and Prychitko David (editors) (1998). Market Process Theories. Aldershot: Edward Elgar Publishing.

Fisher, Franklin (1983). Disequilibrium Foundations of Equilibrium Economics. Cambridge: Cambridge University Press.

Hayek, F.A. (1948). Individualism and Economic Order. Chicago: University of Chicago Press.

Hayek, F.A. (1974). “The Pretence of Knowledge," American Economic Review, 79(6): 3 -7 .

Kirzner, Israel M. (1973). Competition \& Entrepreneurship. Chicago: University of Chicago Press.

Kirzner, Israel M. (1992). The Meaning of Market Process: Essays in the Development of Modern Austrian Economics. New York: Routledge.

Kirzner, Israel M. (1998). "Coordination as a Criterion for Economic 'Goodness'," Constitutional Political Economy, 9: 289 - 301.

Klein, Daniel (forthcoming). "Unfolding the Alleory behind Market Communication and Social Error and Correction," The Adam Smith Review.

Klein, Daniel (2005). "A Plea to Economists Who Favour Liberty: Assist the Everyman," IEA Occasional Paper No. OP 118.

Klein, Daniel (2009). "In Adam Smith's Invisible Hands: comment on Gavin Kennedy," Econ Journal Watch, 6(2): 264 - 279. 
Klein, Daniel and Lucas, Brandon (2009). "In a Word or Two, Placed in the Middle: The Invisible Hand Smith's Tomes," GMU Working Paper in Economics No 09-02.

Klein, Daniel and Orsborn, Aaron (2009). "Concatenate coordination and mutual coordination,” Journal of Economic Behavior \& Organization, 72: 176 - 187.

Leijonhufvud, Axel (1981). "The Wicksell Connection: Variations on a theme," in Information and Coordination: Essays in Macroeconomic Theory. Oxford: Oxford University Press.

Mises, Ludwig von (1949). Human Action: A Treatise on Economics. San Francisco: Fox and Wilkes.

Smith, Adam. (1759 [1990]). The Theory of Moral Sentiments. Indianapolis: Liberty Fund.

Smith, Adam (1776 [1990]). An Inquiry into the Nature and Causes of the Wealth of Nations. Indianapolis: Liberty Fund. 